\title{
.56Pemanfaatan Studi Nilai-Nilai Profetik dalam Pembelajaran Sastra di Perguruan Tinggi
}

\author{
Adenarsy Avereus Rahman ${ }^{\mathbf{1}, \text { Andayani }^{2} \text {, Sarwiji Suwandi }}{ }^{\mathbf{3}}$, Budhi Setiawan ${ }^{\mathbf{4}}$ \\ Program Doktor Pendidikan Bahasa Indonesia, Universitas Sebelas Maret Surakarta \\ Adenarsy.avereus@gmail.com¹, andayani@staff.uns.ac.id², \\ sarwijiswan@staff.uns.ac.id buset.74@gmail.com $^{4}$
}

DOI: https://doi.org/10.32528/bb.v6i2.5628

First received: 28-07-2021

Final proof received: 23-10-2021

\begin{abstract}
ABSTRAK
Nilai profetik mengandung nilai-nilai terpuji yang dicontohkan oleh Nabi Muhammad saw, tidak hanya diimplementasikan dalam kehidupan seharihari, nilai profetik dapat diimplementasikan dalam karya sastra.di sisi lain nilai profetik dapat digunakan sebagai bahan pembelajaran sastra, khususnya diperguruan tinggi secara akademisi memiliki tingkat pemahaman yang tinggi. Penelitian ini bertujuan untuk mendeskripsikan dan menjelaskan 1) implementasi nilai profetik pada novel Bulan Nararya karya Sinta Yudisia. 2) sebagai bahan referensi dalam pembelajaran sastra, 3) sebagai sarana menanamkan nilai pendidikan karakter. Penelitian ini menggunakan metode kualitatif.Teknik pengumpulan data menggunakan dokumentasi dan wawancara, bentuk data berupa kata atau kalimat yang mengacu pada penelitian, validasi data menggunakan trianggulasi sumber data dan teori, teknik analisis menggunakan analisis isi. Hasil penelitian ini (1) Menunjukan bahwa studi nilai profetik bisa dimanfaatkan sebagai materi pembelajaran sastra sebagai pendekatan sastra yang digunakan dalam mengapresiasi karya sastra. (2) Studi nilai profetik dapat dijadikan sarana dalam menanamkan nilai pendidikan karakter yang terdapat dalam karya sastra. Dengan adanya penelitian ini mampu memberikan pengalaman belajar baru dengan menggunakan kajian baru dengan tujuan memperluas khazanah pengetahuan tentang sastra.

Kata Kunci: Nilai profetik; Nabi Muhammad SAW; Pembelajaran Sastra; Perguruan Tinggi.
\end{abstract}

\begin{abstract}
Prophetic values are commendable values that were put on act by prophet Muhammad PBUH. Not only are they implemented in daily basis, they are also implemented in literature. Furthermore, prophetic values are included in linguistics course which demand high understanding. This study is done to describe and explain 1) the implementation of prophetic values in a novel written by Sinta Yudisia called Bulan Nararya, 2) as a reference in linguistics course, and 3) as an approach to implement character building in teaching and learning. Qualitative method was used to undergo this study which uses document and interviews to collect data. The data that was collected was in form of words or statements which refer to some
\end{abstract}


studies. To validate the data, triangulation method upon the source and theory was used while to analyse the data, analysation method was used. The results of this study are 1) to show that the study of prophetic values can be implemented as a source of teaching materials and as a linguistic method to appreciate literature work, 2) the study of prophetic values can be used as an approach to implement character building in teaching and learning. This study is expected to give a new learning experience by using new research to enlarge the knowledge of literature.

\section{Key Words: Prophetic Values, Prophet Muhammad PBUH, Linguistics, College}

\section{PENDAHULUAN}

Nilai profetik sebagai wacana keagamaan dapat diimplementasikan dalam karya sastra, sebagai bahan renungan pembaca. Nilai profetik yang menjadi fokus ialah nilai profetik berdasarkan karakter Nabi Muhammad saw. Alasan utama karakter Nabi Muhammad saw menjadi nilai profetik ini, berdasarkan keempat karakter yaitu shiddiq, amanah, fathanah, dan tabligh, karakter utama atau karakter paling menonjol. Sosok Nabi Muhammad sebagai nabi akhir zaman membawa kedamaian dan cinta bagi seluruh umat Islam. Misi keagamaan yang dibebankan kepada Nabi Muhammad saw tugas mutlak dari Allah swt, diibaratkan sebuah jalan maka Nabi Muhammad saw yang menuntun umat Islam kembali ke jalan yang lurus, jalan yang diberkahi Allah swt. Tugas yang mulia menjadikan sosok Nabi Muhammad saw menjadi sosok yang sangat dikagumi baik sikap, perilaku dan bicarannya merupakan teladan umat Islam. Berbagai topik mengkaji tentang Nabi Muhammad saw. salah satunya penelitian ini yang fokus pada nilai profetik Nabi Muhammad saw berdasarkan empat karakter beliau yang diimplementasikan dalam karya sastra salah satunya novel Bulan Nararya karya Sinta Yudisia. Implementasi nilai profetik dalam karya sastra berupa menerapkan nilai-nilai profetik dalam cerita yang digambarkan berdasarkan perisitiwa dan kejadian para tokoh dalam karya sastra. Identifikasi nilai profetik Nabi Muhammad akan berdasarkan keempat karakter Nabi Muhammad saw.

Pembelajaran merupakan suatu kegiatan belajar mengajar yang dilakukan oleh pengajar dan peserta didik sehingga terjadilah komunikasi satu arah dan dua arah. Pembelajaran tidak hanya soal pemberian materi tetapi, terdapat capaian-capaian yang perlu dicapai guna meningkatkan kualitas pelajar dan kualitas pengajar. Chambers \& Gregory (47:2006) menyatakan pembelajaran yang baik mencakup dua hal, pertama siswa harus sadar akan pentingnya meteri yang diajarkan yang nantinya akan memberikan pengetahuan dan pemahaman yang mendalam tentang materi tersebut. Kedua pembelajaran tersebut harus diajarkan dengan metode yang menarik sehingga dapat menggugah pikiran dan minat siswa.

Bagi pengajar memberikan materi kepada peserta didik tidak hanya sebatas paham atau tidak paham, tetapi pengajar juga harus mampu menanamkan nilai-nilai yang terkandung dalam setiap materi yang diberikan Chambers \& Gregory (46:2006) menyatakan seorang pendidik harus berpikir luas dan kreatif tentang pembelajaran tersebut. Terlebih lagi pembelajaran tingkat perguruan tinggi, pendidik harus memperluas minat siswa terhadap materi tersebut sehingga siswa mampu berpikir kritis dan mandiri 
dalam belajar. Pengajar juga harus mampu memahami setiap karakter peserta didik dalam menerima materi yang diberikan. Pengajar juga harus mampu berinovasi terhadap materi yang akan diajarkan dan pengajar juga harus kreatif dalam memberikan materi kepada peserta didik. Dengan menguasai kemampuan di atas pengajar akan lebih ahli dalam penguasaan kelas ketika pembelajaran berlangsung, dan ini bisa dikatakan adanya peningkatan kualitas bagi pengajar. Nilai-nilai target yang diintegrasikan dalam proses pembelajaran di perguruan tinggi meliputi: (1) taat beribadah, (2) jujur, (3) bertanggungjawab, (4) disiplin, (5) memiliki etos kerja, (6) mandiri, (7) sinergis, (8) kritis, (9) kreatif dan inovatif, (10) visioner, (11) kasih sayang dan peduli, (12) ikhlas, (13) adil, (14) sederhana, (15) nasionalisme, dan (16) internasionalisme

Peserta didik juga tidak hanya mendengar apa yang disampaikan oleh pengajar tetapi peserta didik juga harus mampu memahami dan mengilhami materi yang diberikan sehingga nantinya ada output yang nyata setelah pembelajaran dilakukan. Output itu nantinya akan merujuk kepada bagaimana siswa mampu mengaplikasikan materi yang telah diajarkan di luar lingkungan sekolah, bagaimana siswa mampu mengilhami setiap nilai-nilai yang terkadung dalam setiap kegiatan pembelajaran dan bagaimana siswa memiliki pemikiran berlatih tanpa harus dalam kegiatan pembelajaran. Peranan pemilihan materi juga sangat memperngaruhi dalam pembelajaran, pemilihan materi semestinya juga disesuaikan kepada tingkatannya sehingga, baik pengajar dan peserta didik tidak kesulitan dalam pembelajaran. Romansyah (2016:60) menyatakan proses belajar mengajar yang berbasis kompetensi harus didasarkan pada pokok-pokok pikiran bahwa tujuan yang ingin dicapai oleh peserta didik melalui pembelajaran perlu dirumuskan dengan jelas.

Adapun kriteria-kriteria yang harus diperhatikan dalam menyajikan bahan ajar, yaitu: pencantuman tujuan pembelajaran, pengurutan bahan ajar ( penahapan pembelajaran ), penarikan minat dan perhatian peserta didik, pelibatan keaktifan peserta didik, hubungan antar bahan ajar, norma, dan tes atau soal serta pemilihan materi juga harus sesuai dengan kurikulum dan silabus yang ada. Pemilihan materi pembelajaran di tingkat perguruan tinggi lebih luas, ini disesuaikan dengan faktor fisik dan psikologis artinya mahasiswa membutuhkan suasana belajar yang tidak mengikat dan mempunyai kebebasan berekspresi dan berkreasi oleh karena itu peserta didik diharapkan bisa mandiri dalam proses belajar.

Pembelajaran sastra di perguruan tinggi, memiliki beberapa capaian yang harus diperoleh seperti hakikat sastra, sejarah sastra, kritik sastra, pendekatan genre sastra dan apresiasi sastra, selain itu mengeksplorasi sastra juga dapat dilakukan dengan menganalisis karya sastra dengan beberapa pendekatan. Dengan pola pembelajaran seperti itu dapat mendorong peserta didik meningkatkan pengetahuan tentang sastra baik dari segi teori dan prateknya. Peran pendidik di sini dibutuhkan dalam menyampaikan materi pembelajaran, sehingga inovasi dan kreativitas dalam penyampaian juga dibutuhkan. Menganalisis dan mengapresiasi bisa juga dikatakan memahami makna dan nilai dalam karya sastra, oleh karena itu peserta didik juga diharapkan mampu memaknai isi kandungan serta nilai-nilai yang terkandung dalam karya sastra. Nantinya dari proses memaknai isi dan nilai-nilai yang terkandung, peserta didik mampu mengeinternalisasi 
yang didapat dalam kehidupan. Sehingga mendorong terbentuknya hard skill dan keterampilan kepribadian dan perilaku (soft skills) yang dapat diterapkan dalam berbagai situasi dan kondisi.

Materi yang diajarkan seperti hakikat sastra, sejarah sastra, genre sastra, pendekatan sastra dan apresiasi sastra, kritik sastra. Dari materi yang diajarkan dapat diindikasikan bahwa peserta didik akan mampu memahami sastra dari segi teori. Peran pendidik di sini dibutuhkan dalam menyampaikan materi pembelajaran, sehingga inovasi dan kreativitas dalam penyampaian juga dibutuhkan. Bohlin (28:2005) menyatakan pembelajaran sastra menarik minat siswa dalam pembelajaran dikarenakan, sastra terdapat tokoh-tokoh yang disajikan dengan berbagai karakter dan dikisahkan hampir sama dengan kehidupan nyata. Salah satunya profetik yang awal mula diperkenalkan Kuntowijoyo yang kajiannya berfokus kepada humanisasi, liberasi, transendensi Muttaqin (2015:222) menjelaskan bahwa profetik Kuntowijoyo dicetuskan dari Ilmu Sosial Profetik yang merumuskan tiga nilai yaitu Humanisasi, Liberasi dan Transendensi sebagaimana terkandung dalam surat Ali Imran, ayat 110. Kajian lain dijelaskan dalam 3 instrumen humanisasi, liberasi dan transendendi. Dari teori yang sudah ada ini dapat dikembangkan lagi dengan difokuskan pada makna dari prophetic yaitu nabi.

Makna nabi ini akhirnya menjurus ke Nabi Muhammad dikarenakan sosok tauladan bagi umat Islam, baik perkataan, perilaku dan sifatnya patut dicontoh. Nabi Muhammad merupakan nabi terakhir atau nabi penutup sebagai penyempurna ajaran-ajaran sebelumnya. Nilai profetik Nabi Muhammad saw contoh untuk semua umatnya, penyempurna ajaran Allah swt. Kebbi (2012:5) Nabi Muhammad saw merupakan contoh yang sempurna baik dari sifatnya, cara beliau makan, berpakaian, berinteraksi, menjalankan tugas-tugas agamanya merupakan contoh yang perlu diturunkan. Jamilin, dkk (2017:4874) kehebatan Nabi Muhammad dalam berkomunikas didukung oleh karakter nabi yang menonjol. Oleh karena itu pembaawaan karakter yang kuat berdampak pada gaya komunikasinya yang mudah diterima baik, contohnya ketika berdakwa. Penjelasan diatas memberikan pemahaman bahwa makna profetik sangat luas, tergantung darimana sudut pandang yang akan dijadikan acuan. Pemilihan materi kajian nilai profetik Nabi Muhammad saw ini merupakan bentuk dari berkembangnya sebuah teori dasar yang sudah ada dan dikembangkan lagi guna untuk memenuhi khazanah keilmuan khusunya sastra.

Nilai profetik pertama kali dikemukakan oleh Kuntowijoyo berdasarkan pandangannya pada ayat Al Quran dalam surah Q.S. Al Imran: 110 "Sebagai Kamu adalah umat terbaik yang dilahirkan untuk manusia, menyuruh kepada yang Makruf, dan mencegah dari yang mungkar, dan beriman kepada Allah Ahimsa (2017:2). Dari sini tercipta nilai profetik yang terbagi menjadi 3 bagian yaitu humanisasi, liberasi, dan trasendensi. Oleh karena itu dasar penggunaan kata profetik mengacu pada profetik Kuntowijoyo, dari sini kata profetik dikembangkan lagi berdasarkan makna profetik itu sendiri. Kata nabi bila diterjemahkan dalam Bahasa Inggris menjadi "prophet” jika dalam Islam nabi jamak anbiya seseorang yang mendapatkan wahyu dari Allah. Secara etimologi nabi berasal dari kata naba yang berarti tinggi, atau $n a-b a-a$ artinya berita. Nilai profetik Nabi Muhammad saw ini berdasarkan sifat utama beliau yaitu 
Sifat Shiddiq merupakan sifat yang dapat melekat secara abadi pada diri seseorang atas kesadaran spiritualnya untuk selalu melakukan perbuatan yang benar dan perkataan yang dapat dipercaya. Al-Halwani (2003: 92). Selain itu sifat ini juga menumbuhkan sikap yang terpuji karena kejujuran mengarahkannya untuk melakukan yang terbaik, sesuai dengan norma-norma yang berlaku Kejujuran merupakan satu kata yang memiliki dimensi yang dapat menerangi, mengharumkan menyejukkan, dan rasa manis. Jujur sama juga dengan arti benar, dan ini adalah salah satu dari sifat Rasulullah saw. yang sudah masyhur Jumu'ah (1998: 20). Shiddiq merupakan dimensi spiritualitas yang berwujud kekuatan batin untuk melepaskan diri dari ketidakjujuran, baik dirinya sendiri.

Amanah memiliki makna sesuatu yang dipercayakan yang berupa tindakan yang harus dilakukan, bisa berupa perkataan maupun tindakan. Artinya sesuatu yang telah dibebankan dapat dipertanggungjawabkan atau bisa dipercaya ini sejalan dengan pendapat Munawwir (1971:41) menyatakan Amānatan yang berarti jujur atau dapat dipercaya. Amanah adalah kepercayaan yang diberikan oleh Allah SWT, kepada makhluknnya. Amanah merupakan sifat yang berkaitan erat dengan tanggungjawab sebagai manusia dalam menjalankan kewajiban, tugas, pekerjaan, dalam bidang apapapun yang diberikan atau dibebankan sesuai dengan kemampuan dan atas dasar kepercayaan. Abidin \& Khairudin (2017:120) menyatakan mengenai tanggung jawab manusia, baik kepada Allah SWT yang menciptakannya maupun terhadap sesama makhluk. Amanah yang merupakan segala sesuatu yang dipikul atau ditanggung manusia, baik sesuatu terkait dengan urusan agama maupun urusan dunia, baik terkait dengan perkataan maupun dengan perbuatan dimana puncak amanah adalah penjagaan dan pelaksanaan.

Fathanah ini harus dimiliki oleh seseorang dalam menjalankan amanah yang diembankan kepadanya dapat dilaksanakan dengan baik dan benar serta sanggup memecahkan berbagai permasalahan yang dihadapi secara cerdas dan tepat. Tanpa sifat fathanah ini, seorang tidak akan mampu menangkap dan memahami esensi fenomena alamkebijaksanaanya dalam mengambil keputusan, kemampuannya memahami hikmah dari fenomena yang dihadapi, hingga kesadaran spiritualitasnya yang tinggi. Secara sederhana kecerdasan dalam konsep fathanah ini merupakan perpaduan dari kemampuan manusia yang cerdas dalam bidang emosionalitas, rasionalitas dan spiritualitas secara sekaligus.

Tabligh adalah mengajak atau menyampaikan sekaligus memberikan suatu contoh kepada orang lain untuk melakukan perbuatan yang benar di dalam kehidupan seharihari. Asal kata tablig adalah ballagha yuballighu tablighan kata dalam Bahasa Arab artinya menyampaikan, sehingga secara istilah arti tabligh menyampaikan ajaran-ajaran Islalm yang ada dalam Al Quran dan Hadist kepada manusia. Disisi lain tabligh merupakan daya instrinsik manusia dalam upaya menyampaikan dan menyeru terkait apa yang telah dinilai benar secara moral, rasional dan spiritual. Kemampuan ini tumbuh atas kesadaran dirinya dengan fungsi dan tanggung jawab yang seharusnya memang dijalani.

Berdasarkan penjelasan di atas dapat disintesiskan bahwa kajian profetik dapat dikembangkan lagi beradasarkan sudut pandang yang berbeda, tanpa harus merubah makna dari prophetic itu sendiri. Di sisi lain dengan pemahaman yang baru bisa di manfaatkan dalam pembelajaran sastra diperguruan tinggi. Maka dari itu penelitian ini 
ingin mengkaji kebermanfaatan nilai profetik dalam pembelajaran sastra diperguruan tinggi. Nilai profetik ini mengacu kepada empat sifat Nabi Muhammad saw Shiddiq, Amanah, Fathanah, dan tabligh. Di sisi lain penelitian ini juga bertujuan memperluas kajian pembelajaran sastra, menciptakan dan memperkenalkan variasi kajian dalam pembelajaran sastra sehingga adanya hasil yang bervariasi pula dalam mengapresiasi karya sastra

\section{METODE PENELITIAN}

Penelitian ini menggunakan pendekatan deskriptif kualitatif, Willig (2008:8) menyatakan penelitian kualitatif memiliki tekstur penelitian berdasarkan fenomena, pengalaman yang dialami oleh peneliti maupun peserta penelitian tersebut. Di sisi lain Sherman \& Webb (2006:6) menyatakan tujuan dari penelitian kualitatif menjelaskan dan mendeskripsikan kejadian dan pengalaman dan bukan untuk mendeskripsikan. Penelitian kualitatif mempelajari fenomena yang ada dilingkungan sekitar secara alami. Interpretasi peneliti dan peserta akan berkontribusi dalam penelitian ini. Sumber data yang digunakan terdapat dua yaitu data primer merupakan data dari hasil wawancara dengan informan. Adapun sumber data sekunder merupakan data tambahan yang relevan dengan penelitian ini seperti jurnal dan laporan-laporan, catatan, buku, majalah, artikel, buku-buku sebagai teori. Teknik pengumpulan data menggunakan teknik dokumentasi dan wawancara, teknik analisis data menggunakan analisis isi yang bertujuan untuk membahas secara mendalam terhadap suatu informasi. Validasi data menggunakan trianggulasi teori dan sumber data.

\section{PEMBAHASAN}

\section{A. Nilai Profetik Novel Bulan Nararya Karya Sinta Yudisia Shiddiq}

Kejujuran seorang ayah juga bisa dilakukan oleh Pak Robin. Walau arak telah mengotori pikiran dan hidupnya tetapi demi anak yang ia sayangi, Pak Robin mampu menyampaikan kebenaran yang dialami oleh Sania. Seperti dalam kutipan di bawah ini.

Dia mengusap matanya yang basah. Menggelengkan kepala kasar. "Memang aku bukan yang hamil dan mengandung Sania, Bu. tapi sayangku sama anakku lebih besar dari Saya mamanya kepada dia. kalau aku bisa hamil, akan ku kandungan aku sendiri. bukan aku yang mukul dia tapi mama sama neneknya. Yudisia (2013:116)

Berdasarkan kutipan di atas dapat dijelaskan bahwa kejujuran yang ditampak tokoh bapak Sania, merupakan kejujuran yang timbul dari hati nurani. Bapak Sania memang mempunyai prilaku yang buruk tetapi kasih sayangn kepada anaknya tidak pernah pudar. Kejujuran yang ditampakkan kejujuran yang alami, kejujuran yang pastinya ditampakan oleh orangtua kepada anaknya.

\section{Amanah}


Seorang manusia biasa, pasti seseorang sedang memiliki masalah yang harus dihadapinya. Tetapi sebagai seorang terapis, ia harus mengesampingkan egonya untuk menangani orang-orang yang lebih menggantungkan masalah kepadanya. Seperti dalam kutipan di bawah ini.

Berhadapan dengan orang-orang macam Diana membuatku kikuk. Dia punya masalah dengan Yudhistira, aku punya masalah dengan Angga. Orang-orang seperti Diana mempercayakan kehidupan cinta dan perkawinan mereka pada terapi sepertiku dan Mozza, yang juga tak memiliki hubungan ikatan yang kokoh. Hanya karena berpegang teguh pada kode etik, aku tetap duduk manis, mendengarkan saksama keluhannya. Memberikan respon minimal dan membantunya menemukan gambaran emosi. Yudisia (2013:40)

Bertanggungjawab tidak bisa hanya dilakukan dengan bicara saja tetapi harus ada tindakan nyata sebagai bentuk seseorang yang diberikan tanggungjawab mampu menjalankan amanahnya dengan baik. Bersikap profesional dalam dunia kerja merupakan bentuk tanggungjawab, menjaga perilaku dan gaya bicara sebagai bentuk totalitas seseorang dalam menjalankan amanahnya.

\section{Fathanah}

Rara sebagai seorang terapis, membuatnya berfikir lebih kritis dalam menghadapi masalah pasien yang semakin hari semakin beragam. Rara ingin menerapkan metode-metode yang tidak biasa dalam menangani pasiennya untuk pengobatan yang lebih modern dan dapat menghasilkan perubahan yang lebih cepat dari cara konvensional. Seperti dalam kutipan di bawah ini.

"Moza, apa yang kita terapkan selama ini juga sesuatu yang telah mentah-mentah. nggak ingin berdebat hal itu. Aku justru ingin kita kembali pada sesuatu yang genuine."

Genuine? maksudmu?

"orang banyak kembali pada asal sebab kita mengenal individual differences. Sekarang ada pengobatan ala Cina atau Jepang, gaya relaksasi ala Yoga dan meditasi yang notabene berasal dari budaya India dan Tibet, metodologi pendidikan ala Cina, pengasuhan anak gaya jepang. Itu inti transpersonal,? Bahwa kita dapat memilih apa yang sesuai agar kita. Entah mau memilih akar religi, budaya, kepercayaan. Yudisia (2013:34)

Kecerdasan seseorang tidak bisa dinilai hanya dengan kemampuan berfikir dalam menyelesaikan berbagai masalah. Kecerdasan seseorang juga dapat dilihat kemampuannya berfikir untuk lebih bisa menjadi manusia yang lebih maju dan bermanfaat terhadap lingkungannya. Terus berusaha untuk belajar merupakan perilaku cerdas yang ditunjukan Rara, keinginannya untuk memperbaharui ilmu pengetahun bentuk dari ingin menjadi individu yang memiliki pemikiran luas terkini. 


\section{Tabligh}

Masalah akan semakin berat jika hal yang sepele dibiarkan begitu saja. Seperti kebiasaan-kebiasaan penting dalam bersikap baik. Apalagi membiasakan hal yang baik kepada anak kecil atau orang-orang berlabel skizofrenia membuat terapis harus senantiasa memberikan bimbingan untuk memberi pemahaman tentang kebenaran. Seperti dalam kutipan di bawah ini.

Farida tidak salah. Sania yang seharusnya belajar batas perilaku. Masalah kepemilikian adalah disiplin yang harus paling awal diajarkan. Selain kepemilikikan, Sania juga harus belajar bertanggung jawab. Aku mengajarkannya mencium kotoran seninya yang bercampur bunga-bunga terinjak. Kuambil, kuciumkan ke wajahnya.

" bau?" tanyaku

" bau," wajahnya Sania cemberut jijik."

"kalau gitu, kita bersihkan.” Yudisia (2013:170)

Menyampaikan ajaran kebaikan merupakan konteks yang sangat luas, karena kebaikan bisa memasukin ruang lingkup agama atau sosial. Dalam kehidupan sosial banyak nila-nilai luhur yang hidup berdampingan dengan manusia sebagai bentuk menjaga etika dalam bersosialisasi. Rara memberikan pemahaman terhadap Sania tentang baik dan buruk dalam berprilaku dengan sesama.

Berdasarkan pembahasan keempat nilai profetik di atas dapat disintesiskan, bahwa shiddiq, amanah, fathanah dan tabligh merupakan nilai profetik yang selalu berdampingan dengan kehidupan sosial para tokoh Bulan Nararya. Digambarkan dan dijelaskan melalui percapakan, peristiwa dan kejadian para tokoh. Nilai profetik Nabi Muhammad saw merupakan nilai-nilai yang mudah dipahami dan dimaknai sebagai bentuk internalisasi dalam kehidupan sosial.

\section{B. Pembelajaran Sastra Diperguruan Tinggi}

Pembelajaran sastra diharapkan peserta didik mampu memahami lebih dalam dan detail tentang karya sastra baik secara teori dan prakteknya. Fungsi pembelajaran sastra dapat dikatakan sebagai wahana untuk belajar menemukan nilai-nilai karya sastra yang diajarkan dalam suasana kondusif di bawah bimbingan guru atau dosen. Dalam pengajaran sastra dimungkinkan tumbuhnya sikap apresiasi terhadap hal-hal indah, lembut, dan manusiawi untuk diinternalisasikan menjadi bagian dari karakter anak didik yang akan dibentuk. Salah satu pembelajaran tentang sastra di perguruan tinggi yaitu pendekatan dalam apresiasi sastra. Pendekatan dalam apresiasi sastra biasanya mencakup beberapa kajian seperti psikologi sastra, sosiologi sastra, feminisme dan profetik. Profetik sendiri teori yang mengkaji nilai-nilai yang dianggap memiliki sisi religius.

Studi nilai profetik dapat dijadikan bahan refrensi dalam pembelajaran sastra. Adapun kebermanfaatan dalam pembelajaran sastra sebagai berikut 1) Mampu meningkatkan kemampuan dalam mengilhami nilai-nilai luhur yang terkandung dalam karyanya, 2) Memberikan dampak secara pola pikir dan emosional. Artinya kecerdasaran secara nalar dan psikis akan semakin berkembang dikarenakan mampu memaknai makna yang terkandung dalam isi karya tersebut sebagai suatu refleksi, 3) Secara spiritual 
mampu meningkatkan sisi religiusitas baik dengan manusia maupun tuhan, 4) Secara pendidikan pembelajaran sastra memberikan manfaat yaitu mampu meningkatkan kemampuan mengapresiasi, berkespresi dan menelaah hasil karya sastra.

Nilai profetik dapat dijadikan materi dalam pembelajaran sastra mengacu kepada Profetik Nabi Muhammad saw. Alasan utamanya dikarenakan ingin mengembangkan pembahasan tentang profetik, artinya profetiknya tidak hanya terpaku dalam teori Kuntowijoyo bisa diperluas dengan mengacu arti dari profetik. Alasan lain ingin memperluas pembahasan tentang sifat atau karakter Nabi, yang selama ini hanya seputar meneladani kepemimpinan, sikap berperang, berpolitik, berdagang. Oleh karena itu penelitian ini ingin membahas kebermanfaatan sifat atau karakter Nabi dalam pembelajaran sastra.

Kebermanfaatan studi nilai Profetik juga ditinjau dari hasil wawancara dengan Hilmiyatun dosen Universitas Hamzanwadi Lombok dan Ahmad Bachtiar, M.Pd Dosen Universitas Negeri Jakarta. Kebermanfaatn studi nilai profetik Nabi Muhammad saw, ditinjau dari pengajar dalam memanfaatkanya pada pembelajaran sastra tentunya. Pembelajaran sastra yang didalamnya terdapat materi pendekatan sastra pada mata kuliah Kajian Prosa Fiksi Indonesia, Teori Sastra, Apresiasi Sastra, nantinya materi studi nilai profetik Nabi Muhammad bisa diberikan sebagai referensi pembelajaran yang baru. Memberikan materi pembelajaran sastra tentang pendekatan sastra dengan tujuan peserta didik mampu memahami, menganalisis, mengrkitik karya sastra sehingga, peserta didik akan mendapatkan luaran. Luaran tersebut baik berupa data hasil analisis, mampu menyesuaikan karya sastra dengan pendekatan yang akan dilakukan dan lebih memahami berbagai bentuk pendekatan dalam karya sastra.

Wawancara pertama dilakukan dengan Hilmiyatun dosen Universitas Hamzanwadi Lombok berdasarkan hasil wawancara bahwa nilai profetik Nabi Muhammad bisa dijadikan materi pendekatan dalam pembelajaran karya sastra. kesesuaian tersebut ditinjau bahwa karakter Nabi Muhammad saw yang secara tidak langsung juga melekat kepada setiap individu, hanya saja perlu mengasah karakter tersebut agar menjadi lebih menonjol. Mengasah sebuah karakter bisa dilakukan dengan berbagai cara, salah satunya memberikan pembelajaran tentang karya sastra, tidak hanya untuk dinikmati tetapi juga dipahami dan dihayati makna yang terkandung dalam karya tersebut. Sehingga, adanya umpan balik yang dirasakan setelah membaca atau mengapresiasi karya sastra.

Kesesuaian nilai profetik Nabi Muhammad juga ditinjau dari sosok beliau yang merupakan suri tauladan bagi seluruh umat manusia khususnya umat Islam. Segala perkataan dan perilakunya merupakan contoh bagi umat Islam sehingga, karakter beliau dapat dijadikan bahan kajian untuk nilai Profetik yang nantinya dapat diberikan sebagai bahan materi pembelajaran sastra. Mengembangkan teori profetik yang sudah ada merupakan bentuk kedinamisan sebuah pengetahuan untuk terus berkembang guna memenuhi kebutuhan keilmuan peserta didik. Karena dengan seiring berkembangnya jaman, ilmu akan terus berkembang memenuhi kebutuhan manusia. Kebutuhan yang mendesak akan berdampak kepada para ilmuan untuk melakukan berbagai penelitian guna menemukan sebuah kajian baru dan, secara tidak langsung kajian lama akan 
bergeser tergantikan dengan kajian baru untuk mengikuti perkembangan jaman. Sama hal yang dengan nilai profetik Nabi Muhammad saw yang dikembangkan dari kajian profetik Kuntowijoyo, ini memberikan pola pikir yang baru dalam melihat topik tentang profetik.

Berdasarkan hasil wawancara dengan Hilmiyatun dosen Universitas Hamzanwadi Lombok dapat disintesiskan bahwa nilai profetik Nabi Muhammad saw dapat dijadikan materi dalam pembelajaran sastra. Nilai profetik Nabi Muhammad saw mengandung nilai-nilai terpuji yang dapat dijadikan refleksi atau bahan renungan dalam mengapresiasi karya sastra. Ini merupakan gagasan yang bagus untuk mengembangkan Nilai profetik untuk menjadi bahan kajian yang luas dan inovatif guna memberikan variasi dalam pembelajaran karya sastra. Ide untuk mengembangkan teori profetik ini guna untuk mengisi celah yang masih kosong dalam kajian Profetik sebelumnya yang bisa dimanfaatkan sebagai materi pembalajaran sastra diperguruan tinggi.

Wawancara kedua dilakukan dengan Ahmad Bachtiar, M.Pd Dosen Universitas Negeri Jakarta, berdasarkan hasil wawancara bahwa nilai profetik Nabi Muhammad bisa dijadikan materi pendekatan dalam pembelajaran karya sastra. Dikarenakan teori nilai profetik Nabi Muhammad saw merupakan gagasan yang timbul dari Profetik Kuntowijoyo yang artinya masih relevan untuk dijadikan materi pembelajaran sastra. Karakter beliau yang kuat sangat bisa dijadikan bahan pembelajaran dalam kehidupan sehari-hari karena, latarbelakang beliau sebagai nabi terakhir, nabi akhir jaman pastinya akan memberikan contoh kepada seluruh umat manusia untuk berbuat baik dan menjauhi yang dilarang. Segala sesuatu yang berhubungan Nabi Muhammad saw baik pola pikir, perkataan, perilaku dan karakter beliau bisa dijadikan bahan pembelajaran. Kebermanfaatan tersebut bisa diimplementasikan salah satunya dengan memasukannya di dalam pembelajaran karya sastra.

Pembelajaran karya sastra tidak hanya membahas tentang jenis-jenis karya sastra, pemakaian bahasa dalam karya sastra tetapi membahas cara memaknai sebuah karya dengan berbagai pendekatan yang dilakukan. Berbagai jenis pendekatan dalam karya sastra memiliki fungsi yang berbeda-beda pula, contohnya psikologi untuk mengetahui sisi psikis dalam tokoh, feminisme untuk mengetahui kesetaraan gender dalam sebuah karya sastra. Kajian Nilai Profetik Nabi Muhammad saw untuk mengetahui penggunaan karakter Nabi Muhammad saw sebagai bentuk menanamkan nilai-nilai terpuji yang dapat dijadikan bahan renungan dan refleksi diri. Di sisi lain menanamkan profetik Nabi Muhammad akan memberikan pemahaman mendalam tentang makna sesungguhnya shiddiq, amanah, tabligh dan fathanah dan secara tidak langsung peserta didik akan termotivasi untuk mengamalkan yang telah dipelajari, sekaligus melakasanakan sunnah nabi.

Berdasarkan wawancara di atas dapat disintesiskan bahwa Nilai Profetik Nabi Muhammad saw bisa dijadikan materi pembelajaran karya sastra. Dengan karakter beliau yang kuat pastinya segala sesuatu yang dicontohkan dapat dijadikan teladan yang dapat dijadikan pelajaran baik secara formal dan informal. Mengamalkan karakter nabi secara tidak langsung melaksanakan sunnah nabi. Oleh karena itu nilai Profetik Nabi Muhammad saw bisa dijadikan refrensi dalam pembelajaran sastra berdasarkan 
penjelasan diatas, sejatinya apa yang dicontohkan Nabi Muhammad saw dapat dijadikan suri tauladan tergantung penempatannya dalam kehidupan sehari-hari.

Wawancara kedua narasumber dapat disintesiskan, bahwa nilai profetik Nabi Muhammad saw memiliki kebermanfaatan sebagai bahan referensi pembelajaran karya sastra. Ditinjau dari nilai-nilai terpuji yang terdapat dalam diri Nabi Muhammad saw dapat dimanfaatkan sebagai materi dalam memahami dan memaknai nilai-nilai terpuji Nabi Muhammad saw yang terimplementasikan dalam karya sastra. kebermanfaatan ini juga dinilai dari sosok Nabi Muhammad saw sebagai nabi akhir zaman dan nabi penutup, segala yang dicontohkan patut dilaksanakan sebagai bentuk keimanan dan ibadah umat manusia kepada nabinya.

Artikel yang berjudul yang New Nigeria': A Socioreligious Dimension Of Prophetic Envisioning ditulis oleh Ishaya Anthony, seiring dan sejalan dengan penelitian yang telah dilakukan. Jika penelitian Ishaya Anthony berfokus pada menciptakan masyarakat bebas korupsi, kekerasaan hidup dengan keadilan dan toleransi yang kuat, salah satunya dengan lagu religi berjudul " Nigeria baru” yang mengandung unsur profetik. Lagu profetik diharapkan membawa dampak positif kepada setiap pendengarnya, mampu membangkitkan sisi religius. Adanya perubahan baik secara sikap dan pikiran untuk berbuat kebaikan. Tidak hanya sekedar mendengarkan pendengar juga mampu mengilhami setiap bait dalam lagu, merenungi kehadian tuhan sebagai bentuk religi antara manusia dan tuhannya. Persamaan dengan penelitian yang dilakukan penggunaan kata Profetik yang mengacu kepada makna kenabian, mengilhami setiap kebaikan dan mnegimplementasikan ke dalam kehidupan sehari-hari meskipun perbedaan dalam konteks profetik tidak sama jika ditinjau dari sisi keagamaan. Jika Islam mengacu kepada Nabi Muhammad saw, maka jika profetik dalam artikel New Nigeria': A Socioreligious Dimension Of Prophetic Envisioning mengacu pada kitab umat Kritiani. Artinya penelitian ini relevan dari segi kata dan makna "profetik", meskipun melihat sisi profetik dari sudut pandang lagu yang didalamnya masih mengandung sisi religi.

\section{Pendidikan Karakter}

Pendidikan karakter merupakan suatu upaya proaktif yang dilakukan baik oleh sekolah maupun pemerintah, untuk membantu peserta didik mengembangkan inti pokok dari nilai-nilai etik dan nilai-nilai kinerja, keuletan, kejujuran, kerajinan, dan ketabahan, tanggung jawab, menghargai diri sendiri dan keadilan ini sama halnya dengan pendapat Samani dan Hariyanto (2012:43) pendidikan karakter telah menjadi sebuah pergerakan pendidikan yang mendukung pengembangan sosial, pengembangan emosional, dan pengembangan etik para siswa. Zubaedi (2013:14) pendidikan karakter diartikan sebagai the deliberate us of all dimentions of school to foster optimal character development (usaha kita secara sengaja dari seluruh dimensi kehidupan sekolah untuk membantu pegambangan karakter dengan optimal).

Pendidikan karakter merupakan upaya penanaman kecerdasan dalam berikifir, penghayatan dalam bentuk sikap, dan pengamalan dalam bentuk perilaku yang sesuai dengan nilai-nilai luhur yang menjadi jati dirinya, diwujudkan dalam interaksi dengan tuhannya, diri sendiri antarsesama dan lingkungannya. Arthur (115:2003) menyatakan 
pendidikan karakter berfokus kepada nilai-nilai dasar kebajikan, berperilaku dengan baik, memberikan materi yang mengandung nilai moral, menjunjung tinggi keteladanan. Nilainilai luhur tersebut antara lain: kejujuran, kemandirian, sopan santun, kemuliaan sosial, kecerdasan berfikir intelektual dan berikfir logis.

Menanamkan pendidikan karakter bisa melalui media apa saja, misalnya dicontohkan dengan cerita-cerita fiksi, menonton film, perilaku keluarga, itu merupakan contoh dengan bentuk informal. Formalnya pendidikan karakter dicontohkan atau diajarkan dalam pembelajaran di lingkungan akademisi, baik melalui teori atau menyisipkan dalam materi pembelajaran. Memberikan nilai-nilai pendidikan karakter melalui kegiatan belajar mengajar bisa dicontohkan dengan memberikan materi pembelajaran tentang nilai profetik Nabi Muhammad saw. Nilai profetik Nabi Muhammad mencakupu empat aspek, setiap aspeknya mempunyai peranan penting setiap sendi kehidupan. Empat aspek tersebut yaitu shiddiq, amanah, tabligh, fathanah. Shiddiq berkaitan dengan kejujuran, amanah memiliki arti bertanggungjawab, tabligh menyampaikan ajaran yang berisikan tentang kebaikan dan fathanah kercerdasan baik secara kognitif dan spriritual.

Empat aspek tersebut pasti sangat dibutuhkan dalam menjalani kehidupan seharisehari, disadari atau tidak keempat aspek tersebut pernah dialami oleh seyiap manusia. Oleh karena itu perlunya memberikan pemahaman secara mendalam tentang nilai profetik Nabi Muhammad saw. ini merupakan manfaat dari nilai profetik Nabi Muhammad saw, artinya selain bisa digunakan dalam pembelajaran, secara tidak langsung pengajar akan menanamkan nilai-nilai profetik kedalam peserta didik. Nilai profetik Nabi Muhammad saw merupakan nilai profetik yang berisikan nilai-nilai luhur yang dapat menjadi teladan bagi seluruh umat manusia. Kebermanfaatan studi nilai profetik Nabi Muhammad saw sebagai nilai pendidikan karakter ditinjau dari hasil wawancara dengan Hilmiyatun dosen Universitas Hamzanwadi Lombok dan Ahmad Bachtiar, M.Pd Dosen Universitas Negeri Jakarta.

Wawancara pertama dilakukan dengan Hilmiyatun dosen Universitas Hamzanwadi Lombok berdasarkan hasil wawancara bahwa nilai profetik Nabi Muhammad bisa dijadikan sebagai nilai pendidikan karakter ini didasari oleh nilai-nilai kebaikan yang terkandung dalam nilai profetik Nabi Muhammad saw. Memahami dan melaksanakan keempat nilai profetik tersebut sama seperti mengamalkan yang diajarkan Nabi Muhammad saw kepada umatnya. Keempat nilai profetik tersebut tidak hanya mengajarkan sebatas pengertian tetapi filosofis. Artinya makna kejujuran tidak hanya diperlihatkan dengan perilaku saja melainkan dimulai dari hati, bicara dan dimplementasikan dengan perilaku. Kejujuran juga tidak bisa dimaknai antar individu tetapi kejujuran juga mempunyai relasi dengan Sang pencipta sebagai bentuk ketulusan hati. Amanah bertanggungjawab dalam memaknainya tidak sekedar selesai dalam menyelesaikan tugas. Bertanggungjawab harus bisa dimaknai lebih dalam dan luas misalnya, bisa bertanggungjawab dengan bicaranya, perilakunya, kata hatinya yang terpenting bertanggungjwab kepada Allah sebagai bentuk ibadah.

Mahluk hidup khususnya umat Islam mempunyai tanggungjawab yang besar kepada Allah swt misalnya melaksanakan sholat, zakat, puasa, melaksanakan penrintah 
dan menjauhi larangannya. Tabligh dimaknai dengan selalu menyirakan ajaran Allah swt baik sunnah dan wajib sama seperti berdakwah. Tabligh/berdakwah jaman sekarang tidak harus dengan mengadakan acara besar baru bisa mengajarkan atau menyerukan ajaran Allah, harus ada perubahan seiring berkembangnya jaman. Jaman sekarang semua komunikasi bisa dilakukan lewat internet, artinya semua sosial media bisa digunakan sebagai sarana untuk tetap mengajarkan ajaran Allah swt. Konteks tabligh juga bisa diperluas, segala sesuatu tentang kebaikan wajib untuk disampaikan baik itu masalah kecil ataupun besar. Fathanah memiliki arti kecerdasan, kecerdasan tidak selalu berhubungan dengan kognitif. Kecerdasan juga bisa mencakup kecerdasan spiritual, artinya kecerdasan yang berhubungan dengan indra keenam bisa juga disebut memiliki perasaan yang sensitif terhadap sesuatu hal. Kecerdasan spriritual diperoleh dengan ketekunan dalam beribadah, sehingga Allah swt akan menuntunnya untuk memiliki perasaan yang kuat (sensitif)

Wawancara kedua dilakukan dengan Ahmad Bachtiar, M.Pd Dosen Universitas Negeri Jakarta, berdasarkan hasil wawancara, nilai profetik Nabi Muhammad bisa dijadikan sebagai nilai pendidikan karakter. Nilai profetik Nabi Muhammad saw, mengandung nilai-nilai terpuji. Di sisi lain Nabi Muhammad saw merupakan Nabi yang segala bicara dan perilakunya dijadikan teladan, sehingga relevan jika sifat beliau dijadikan nilai pendidikan karakter. Nilai profetik Nabi Muhammad saw mengajarkan berprilaku jujur, amanah, tabligh dan cerdas dengan semestinya. Terdapat nilai filosofis tersendiri ketika nilai profetik Nabi Muhammad saw sebagai nilai pendidikan karakter. Mengajarkan berserta mengamalkan yang diajarkan Nabi Muhammad saw merupakan bentuk menjalankan sunnah Nabi dan ketaqwaan sebagai umat muslim

Menginternalisasi nilai profetik dalam kegiatan pembelajaran, memberikan dampak secara psikologi terhadap peserta didik. Terlebih lagi peserta didik dengan tingkatan mahasiswa, tingkat pemahamannya sudah tinggi. Mempermudah pengajar memberikan pemahaman tentang nilai profetik Nabi Muhammad saw sebagai nilai pendidikan karakter. Memberikan pemahaman kepada mahasiswa bisa dilakukan dengan menganalisis atau mengapresiasi karya sastra dengan nilai pendidikan karakter, dengan sendirinya mahasiswa akan menginterpretasinya nilai pendidikan karakter secara mendetail dan mendalam sebagaimana pengetahuan yang telah dimiliki sebelumnya. Secara tidak langsung mahasiswa akan menginternalisasi nilai-nilai tersebut ke dalam dirinya sebagai bentuk mengembangkan diri ke arah yang lebih baik.

Berdasarkan hasil wawancara di atas dapat disimpulkan, nilai profetik Nabi Muhammad saw dapat dijadikan sebagai nilai pendidikan karakter. Ini berlandaskan dari figur beliau sebagai teladan umat muslim. Sejatinya segala bentuk perbuatannya dapat dijadikan teladan dan pelajaran dalam kehidupan sehari-hari. Karakter beliau yang kuat maka dengan mudah diimplementasikan dalam pendidikan formal, pendidik harus berinovasi dalam menyampaikan sebagai materi pembelajaran sehingga mahasiswa akan lebih berminat dalam memahaminya.

Artikel yang berjudul Curriculum design in theology and development: Human agency and the prophetic role of the church yang ditulis oleh Beverley Haddad, seiring dan sejalan dengan penelitian yang telah dilakukan. Jika penelitian Beverley Haddad 
fokus dalam wacana keagamaan dalam mengembangkan kurikulum dengan mengambil sudut pandang profetik gereja. Profetik memliki peran dalam mengembangkan sebuah kurikulum, yang nantinya diimplementasikan dalam sistem pembelajaran. Disisi lain profetik Gereja Beverley Haddad ingin mengajarkan kepada siswa dalam menggunakan wacana keagamaan sebagai salah satu penghubung memahami kompleksitas kehidupan sosial. Luaran yang ingin dicapai terciptanya toleransi antar sesama makhluk sosial. Persamaan penelitian Beverley Haddad dengan penelitian ini terletak pada konteks profetik sebagai wacana keagamaan, mengimplementasikan wacana keagamaan (profetik) dalam bidang akademisi. Dengan tujuan konteks keagamaan ini mampu memberikan dampak postifi dalam diri siswa. Perbedaannya terletak dari sudut pandang dalam melihat profetik, jika profetik Beverley Haddad ditinjau dari sudut pandang Gereja (Kristen) maka, profetik dalam penelitian ini ditinjau dari sisi Islam, berdasarkan Nabi terakhir dalam agama Islam yaitu Nabi Muhammad saw. melihat profetik dari segi pendidikan merupakan bentuk seiring sejalan dengan penelitian yang dilakukan, mengimplemantasikan profetik dalam pembelajaran dilingkungan akademisi dengan harapan peserta didik memiliki karakter yang positif.

\section{SIMPULAN}

Berdasarkan penjelasan di atas dapat disimpulkan, implementasi nilai-nilai profetik Nabi Muhammad saw dalam novel Bulan Nararya sebagai wujud menanamkan nilai-nilai luhur dalam kehidupan sosial dengan tujuan menjadikan setiap individu lebih baik lagi.Di sisi lain mengimplementasikan nilai profetik sebagai bentuk meneladani sifat Nabi Muhammad saw. Nilai profetik Nabi Muhammad saw dapat dimanfaatkan sebagai pembelajaran sastra diperguruan tinggi. ditinjau dari wawancara kedua dosen Bahasa Indonesia dari universitas yang berbeda pula. Tidak hanya sebagai materi dalam pembelajaran sastra, nilai profetik Nabi Muhammad saw juga bisa dimanfaatkan sebagai sarana dalam menanamkan nilai pendidikan karakter. Kebermanfaatn nilai profetik selain ditinjau dari wawancara ahli, nilai-nilai terpuji yang dicontohkan Nabi Muhammad saw patut diamalkan sebagai bentuk menjalankan ibadah sunnah. Karakter maupun figur Nabi Muhammad saw merupakan contoh yang layak dijadikan bahan kajian dilihat dari beberapa artikel yang membahas Nabi Muhammad, sebagai bentuk meneladani baik sikap dan figurnya. Di sisi lain kajian profetik dipandang sebagai bentuk wacana keagamaan yang diharapkan nilai-nilai religi didalamnya membawa dampak positif bagi masyarakat dan lingkungan. Adanya keselaran antara nilai profetik sebagai wacana keagamaan dengan Nabi Muhammad saw sebagai Nabi akhir zaman yang membawa dunia ke zaman yang terang benderang dengan misi agama sebagai pencerah dunia.

\section{REFERENSI}

Al-Halwani, A.F. (2003). Membangun Akhlak Mulia dalam Bingkai al-Quran dan assunnah.Yogyakarta: Al-Manar.

Arthur, J. (2003). .Education with Character The moral economy of schooling. London: RoutledgeFalmer 
Al-Olaqi, F.M.T.S. (2015). The Prophet Muhammad's Leadership: An Islamic View. Advances in Social Sciences Research Journal.59-70.

Anthony, I. (2018). 'New Nigeria': A socioreligious dimension of prophetic envisioning. HTS Teologiese Studies/Theological Studies. 1-7

Abidin, Z., \& Khairudin, F. (2017). Penafsiran Ayat-Ayat Amanah Dalam Al-Qur'an. Jurnal Syahadah. 120-144

Bohlin, K. E. (2005). Teaching Character Education through Literature Awakening the moral imagination in secondary classrooms. USA: Routledge Falmer.

Gregory, M., \& Chamber, E. (2006) Teaching \& Learning English Literature. London: SAGE Publications.

Haddad, B. (2016). Curriculum design in theology and development: Human agency and the prophetic role of the church. HTS Teologiese Studies/Theological Studies.1-8

Hariyanto, dkk. (2012) . Pendidikan karakter. Bandung: PT Remaja Rosdakarya

Jamilin, A. K. (2017). Prophetic Approaches In Communication: A Pilot Analysis Of Hadith Prophet Muhammad. Research Article American Scientific Publishers. $4872-4876$

Jumueah, A. K. (1998). Jujur Mata Uang Dunia dan Akhirat. Jakarta: Pustaka Azzam.

Kebbi, S. (2012). The Impact of Prophet Muhammad's Misconceived Sunnah on the Traditional Muslim's Lifestyle in Tripoli, Lebanon. 3-7.

Mahmud,. (2011). Metode Penelitian Pendidikan. Bandung: CV Pustaka Setia.

Munawir, A. W. (1997) Kamus Al-Munawwir Arab-Indonesia Terlengkap. Surabaya: Pustaka Progresif.

Muttaqin, H. (2015). Menuju Sosiologi Profetik. Sosiologi Reflektif. 219-24.

Nazir, M. (2009). Metode Penelitian. Bogor: Ghalia Indonesia.

Putra, H. S. A. (2017). Paradigma Profetik Islam Epistemologi, Etos, dan Model. Yogyakarta: UGM Press.

Romansyah, K. (2016). Pedoman Pemilihan dan Penyajian Bahan Ajar Mata Pelajaran Bahasa dan Sastra Indonesia. Jurnal Logika. 59-66

Willig, C. (2008). .Introducing Qualitative Research in Psychology. England: Open University Press.

Webb, R. B. \& Sherman, R. R. (2006). drExplorations in Ethnography Series Qualitative Research in Education: Focus and Methods. London: Routledge Falmer.

Yudisia, S. (2014). Bulan Nararya. Surakarta : Indiva Media Kreasi

Zubaedi. (2012). Desain Pendidikan Karakter. Jakarta: Kencana Prenada Media Group 
Rahman, A.A., Andayani, Suwandi, S., \& Setiawan, B. Pemanfaatan Studi Nilai-Nilai Profetik dalam ... 